\title{
Secondary production of gorgonian corals in the northern Gulf of Mexico
}

\author{
Naomi D. Mitchell ${ }^{1}$, Michael R. Dardeau ${ }^{2}$, William W. Schroeder ${ }^{1}$, Arthur C. Benke ${ }^{3}$ \\ ${ }^{1}$ Marine Science Program, The University of Alabama, PO Box 369, Dauphin Island, Alabama 36528, USA \\ ${ }^{2}$ Marine Environmental Sciences Consortium, Dauphin Island Sea Lab, PO Box 369, Dauphin Island, Alabama 36528, USA \\ ${ }^{3}$ Department of Biology, The University of Alabama, Box 870344, Tuscaloosa, Alabama 35487-0344, USA
}

\begin{abstract}
Gorgonians are the most conspicuous sessile macroinvertebrates at many hard-substrate sites in the northeastern Gulf of Mexico. Colonies from 3 sites, an isolated limestone outcropping at less than $2 \mathrm{~m}$ depth off coastal Florida (USA) and 2 exposed shelly sandstone and sandy mudstone carbonate areas at depths of 22 and $27 \mathrm{~m}$ on the inner shelf off Alabama (USA), were sampled to estimate secondary production. Maximum colony ages ranged from 5 to $10 \mathrm{yr}$. Tissue mass for each age class was estimated from determinations of coenenchyme thickness and colony surface area. Secondary production was estimated from colony densities, age distribution, biomass per age class, and the increase in colony biomass between age classes. Production estimates for Leptogorgia hebes at the 2 offshore sites were 2.3 and $6.8 \mathrm{~g}$ ash-free dry mass (AFDM) $\mathrm{m}^{-2} \mathrm{yr}^{-1}$ while production of L. virgulata at the inshore site was $10.5 \mathrm{~g} \mathrm{AFDM} \mathrm{m}^{-2} \mathrm{yr}^{-1}$, values similar to those reported for tropical scleractinian corals. Annual production-to-biomass ratios ranged from 0.37 to 0.45 , indicating similar turnover times at all northern Gulf sites.
\end{abstract}

\section{INTRODUCTION}

Gorgonians are a conspicuous component of marine communities from cold-temperate to tropical climates and from one to several thousand meters depth. Although most species are tropical, several inhabit temperate and subtropical waters off the North American continent (Bayer 1961). Gorgonians typically possess fan shapes and arborescent morphologies which allow them to exploit relatively small amounts of hard substrate while utilizing a large volume of the water column (Barnes 1980). Nonetheless, availability of hard substrate may be a limiting factor for many species (Grigg 1977, Benayahu 1985). In the northeastern Gulf of Mexico, hard substrates on the inner continental shelf are limited to relatively small areas (Curray 1960, Ludwick 1964, Parker et al. 1983. Schroeder et al. 1988a, b, 1989), but when present they host diverse gorgonian-dominated communities (Schroeder et al. 1989).

On the low relief $(<0.25 \mathrm{~m})$ rock-rubble fields characteristic of these hardbottom features, gorgonian colonies provide most of the structural complexity attractive to fishes. Gorgonian colonies also directly furnish habitat, contributing to an increased abundance and diversity of associated organisms. For example, Wendt et al. (1985) found over 1500 individuals representing 135 species on only 9 gorgonian colonies (3 Leptogorgia virgulata, 3 Leptogorgia hebes, and 3 Titanideum frauenfeldui) collected off the Georgia (USA) coast. Gorgonians are clearly important in these communities yet little is known about their basic biological parameters, particularly those of continental shelf species.

To date, no study has addressed the contribution of gorgonians to hard bottom communities. Unlike the primary producers which provide physical structure for most terrestrial and coastal communities, gorgonians are principally secondary producers (i.e. heterotrophic). An assessment of the secondary production of gorgonians, or the amount of tissue produced per unit space per unit time (Waters 1977, Crisp 1984), should thus provide a first step towards understanding functional relationships in these systems. This study compares age distribution, biomass and secondary production of 3 gorgonian populations in the sub- 
tropical waters of the Gulf of Mexico, 2 offshore populations of Leptogorgia hebes on the inner continental shelf of Alabama (USA) and 1 inshore population of L. virgulata $50 \mathrm{~m}$ offshore in north central Florida (USA).

\section{METHODS AND MATERIALS}

Study sites. Site $1\left(30^{\circ} 04^{\prime} \mathrm{N}, 88^{\circ} 13^{\prime} \mathrm{W}\right)$ is $22 \mathrm{~m}$ deep and located in the direct path of typical Mobile Bay, Alabama, estuarine plumes (Abston et al. 1987, Dinnel et al. 1990) (Fig. 1). Site $2\left(30^{\circ} 00^{\prime} \mathrm{N}, 87^{\circ} 57^{\prime} \mathrm{W}\right)$ is $27 \mathrm{~m}$ deep, lies $28 \mathrm{~km}$ east-southeast of Site 1 and is less frequently subjected to direct influence of Mobile Bay plumes. Leptogorgia hebes is the dominant epifaunal species at these 2 sites but occasional specimens of L. virgulata are present. The 2 species investigated here, long considered to represent separate genera (Leptogorgia and Lophogorgia), have recently been united under Leptogorgia (Grasshoff 1988). Substrate at these 2 sites consists of low-relief $(<0.25 \mathrm{~m})$ shelly sandstone slabs and sandy mudstone rubble, often covered by a thin veneer of sand (Schroeder et al. 1989). Site 1 occupies ca $0.01 \mathrm{~km}^{2}$, while Site 2 is representative of a rubble field area ca $1.0 \mathrm{~km}^{2}$.

Site 3 is near St. Theresa Beach, Florida (Fig. 1), 50 m from the beach, at depths of 1 to $1.5 \mathrm{~m}$, in turbid waters of a small bay formed by Alligator Point. Because of its shallow depth, Site 3 is subject to stronger and more frequent wave action (resulting in more intense sand scouring) and greater fluctuations in temperature and salinity than the offshore sites, as well as occasional exposure (once or twice a year during conditions of low tide combined with strong northerly winds). Leptogorgia virgulata is the only gorgonian species at this site. The substrate is a low relief $(<0.25 \mathrm{~m})$ limestone outcrop with scattered rock rubble estimated to cover roughly $0.02 \mathrm{~km}^{2}$ (Gotelli 1988).

Production. Coral production was calculated from the following determinations: (1) total density of coral colonies; (2) age distribution of sampled colonies; (3) colony biomass for each age class; and (4) increase in colony biomass for each age class.

Gorgonian densities were determined from $16.5 \times$ $1.8 \mathrm{~m}$ belt transect counts at offshore sites and from both belt transect and $0.25 \mathrm{~m}^{2}$ quadrat counts at the inshore site. Visual censuses were conducted by divers 3 times in March at Site 1, twice each in December and May at Site 2 and once each season at Site 3. Mean values were used in calculations. Colonies were randomly collected along the belt transects (Site 1 in March 1989, Site 2 in May 1989 and Site 3 in November 1988) for determination of population age structure, biomass and colony surface area.

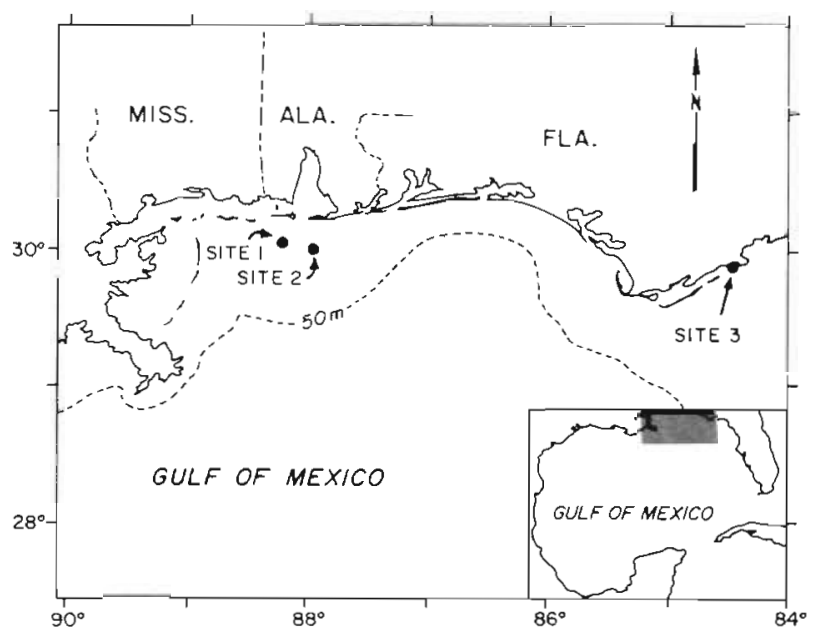

Fig. 1. Leptogorgia hebes, L. virgulata. Study site locations of gorgonian coral populations

The major tissue mass of gorgonian corals consists of individual polyps connected by coenenchyme. This tissue covers all external surfaces, surrounding an internal skeleton (axial rod) in many species. Colony biomass can therefore be determined by multiplying external surface area times the mean coenenchyme thickness times a correction factor for ash-free dry mass (AFDM).

The surface area of the colonies was calculated from a known relationship between surface area of an object and its increase in weight when dipped in water containing a surfactant (Harrod \& Hall 1962, Hicks 1977). This relationship was obtained by regressing manual surface area measurements of 4 large, whole colonies and 10 smaller branches of each species on the weight increase after dipping. The diameter (d) and height ( $h$ ) of each segment of the whole specimens of each species were measured manually. Similar measurements were made on the smaller pieces. Diameter was measured at the midpoint of the branch or section. Surface areas were calculated assuming the shape of a cylinder $($ area $=\pi d h)$, with minor adjustments for blunt end pieces $\left[\pi(d / 2)^{2}\right]$. Surface area measurements were then summed for each colony or piece.

After surface area was obtained manually, each colony or piece was sprayed with a thin coat of varnish to reduce variability due to absorption, weighed to the nearest $\mathrm{mg}$, then dipped for $10 \mathrm{~s}$ in water containing 2 drops of dish washing liquid per liter. Colonies and pieces were weighed again after blotting. Surface area from manual measurements was then regressed on the increase in mass after dipping for each species. The 2 regression equations were used to calculate the surface area of each remaining colony. Twenty-eight 
Leptogorgia hebes from Site 2 and 29 L. virgulata colonies from Site 3 were dipped to determine surface area.

Four colonies of each species were utilized to determine mean coenenchyme thickness. Colonies were laid over a sheet of graph paper and random numbers corresponding to $1 \mathrm{~cm}$ squares were drawn until a sample from each of 3 regions (tips, middle and base) were selected. Coenenchyme within these squares was scraped and saved. Thickness was measured from the surface of the remaining coenenchyme to the axial rod. Thus, surface area (from dipping), multiplied by the mean coenenchyme thickness for that species multiplied by a specific gravity of $1 \mathrm{~g} \mathrm{~cm}^{-3}$, resulted in an estimate of the wet weight of each colony.

Ash-free dry mass was determined for each species using the above coenenchyme samples. Samples were weighed wet to the nearest $0.1 \mathrm{mg}$, dried at $100^{\circ} \mathrm{C}$ for $24 \mathrm{~h}$ and reweighed. They were then ashed at $500^{\circ} \mathrm{C}$ for $3 \mathrm{~h}$, reweighed and AFDM calculated by subtracting the ash from the dry mass. The average ratio of AFDM to wet mass for each species was multiplied by the wet mass of each colony to estimate AFDM. After biomass was determined, and the colony aged by counting growth rings in a cross-section of the base (Mitchell et al. in press), biomass was regressed on age to determine the mean biomass of each age class for each species.

At Sites 2 and 3, age structure was obtained from the same sample of colonies from which biomass was estimated. At Site 1 it was not possible to obtain biomass estimates from the collection analyzed for age structure so biomass was estimated from the equation developed for Leptogorgia hebes from Site 2. Density (no. $\mathrm{m}^{-2}$ ) for each age class (D) was obtained from the fraction of each age class times total density.

Production for each age class was determined from the mean density of colonies for each age class $(\bar{D})$ multiplied by the change in colony biomass $(\Delta W \mathrm{~g}$ AFDM) between each age class per colony. This represents a version of the increment-summation method, $P=\sum(\bar{D} \Delta W)$ (Waters 1977, Benke 1984), where total production $(P)$ is the sum of production for all age classes (Crisp 1984). Total standing stock biomass is the sum of the mean biomass values $(\bar{B}=\bar{D} \times \bar{W})$ for all age classes.

\section{RESULTS}

The strong linear relationship between manual estimates of surface area and increased mass after dipping $\left(\mathrm{r}^{2}=0.96, \mathrm{p}<0.01, \mathrm{~N}=14\right.$ for Leptogorgia hebes $; \mathrm{r}^{2}=$ $0.99, \mathrm{p}<0.01, \mathrm{~N}=14$ for L. virgulata; Fig. 2) justified the use of this technique to estimate surface area for

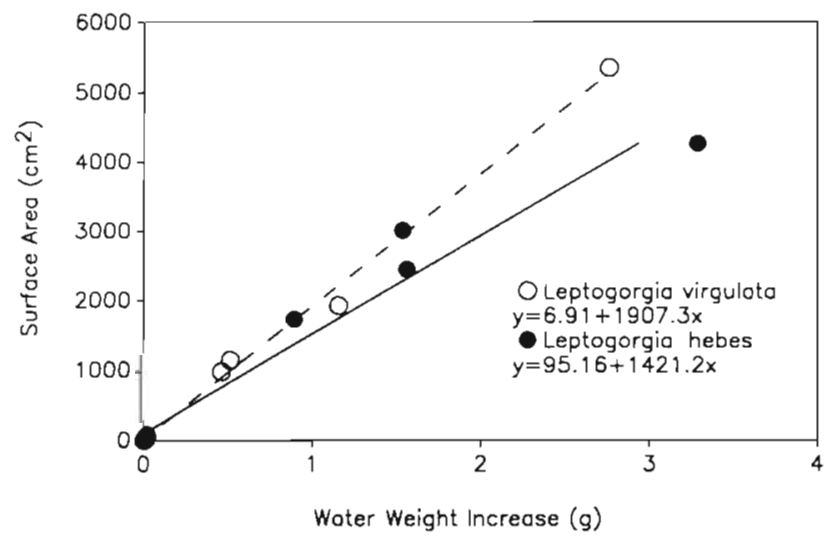

Fig. 2. Leptogorgia hebes, L. virgulata. Surface area regressed on water weight increase of gorgonians after dipping in water containing a surfactant. $\mathrm{N}=14$ for each species; smaller pieces all overlap near the origin

biomass calculations. The mean coenenchyme thickness was $0.065( \pm 0.007 \mathrm{SE}$ ) and $0.073( \pm 0.006 \mathrm{SE}) \mathrm{cm}$ for $L$. hebes and $L$. virgulata, respectively. Surface area for each colony was multiplied by mean coenenchyme thickness for that species and a specific gravity of $1 \mathrm{~g} \mathrm{~cm}^{-3}$ to obtain wet mass per colony. Wet weight of each colony was multiplied by the AFDM conversion factor for that species, $9.27 \%$ ( $\pm 0.40 \mathrm{SE}$ ) and $8.94 \%$ ( $\pm 0.23 \mathrm{SE}$ ) for $L$. hebes and $L$. virgulata, respectively, to obtain the biomass per colony.

Considering the relatively small sample sizes, a regression was felt to provide better estimates of colony biomass for each age class than simply taking the means for each age class. Despite the obviously great variation in biomass within each age class, regressions of biomass on age demonstrated significant relationships $(p<0.01)$ although the $r^{2}$ values were relatively low (Figs. $3 \& 4$ ). The biomass per age

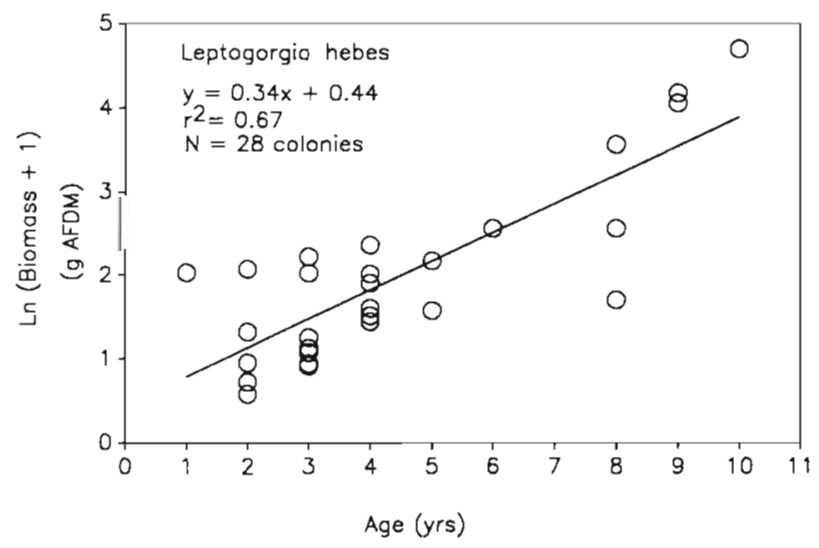

Fig. 3. Leptogorgia hebes. Log transformed biomass (g AFDM) estimates regressed on age classes. See Tables 1 $\& 2$ for biomass рет age class estimated from this regression equation 


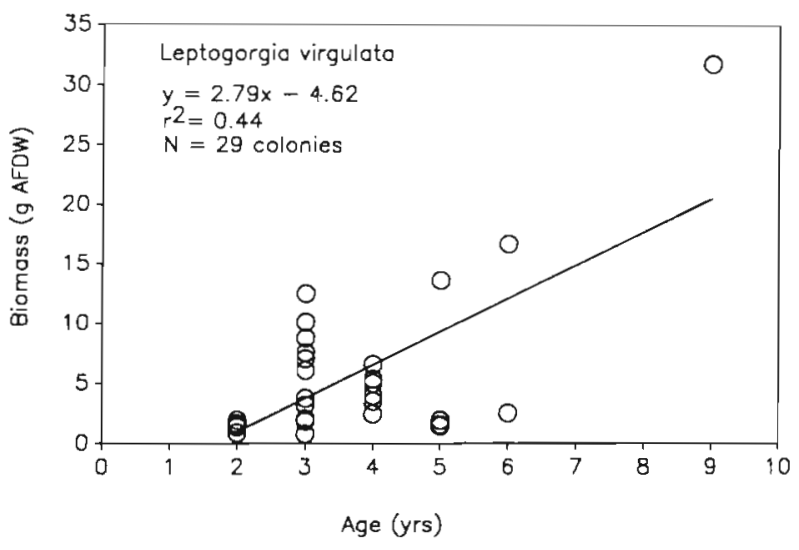

Fig. 4. Leptogorgia virgulata. Biomass (g AFDM) estimates regressed on age classes. See Table 3 for biomass per age class estimated from this regression equation

class for Leptogorgia hebes at Sites 1 and 2 were both extrapolated from the same random sample of colonies collected at Site 2 since it was not possible to make a final collection at Site 1 for biomass estimates. This step seemed reasonable as no differences in population growth characteristics or total branching complexity were found between populations at Sites 1 and 2 (Mitchell et al. in press). A logarithmic transformation of biomass significantly improved the relationship with age for $L$. hebes.

Colony densities determined from belt transects and quadrat sampling were $1.6( \pm 0.26 \mathrm{SE}) \mathrm{m}^{-2}$ at Site 1 , $1.8( \pm 0.40 \mathrm{SE}) \mathrm{m}^{-2}$ at Site 2 , and $4.0( \pm 1.48 \mathrm{SE}) \mathrm{m}^{-2}$ at Site 3. Using age distribution determined from the sacrificed colonies, these total densities were converted into age-specific densities (Tables 1 to 3 ).

Production of Leptogorgia hebes was 2.3 and $6.8 \mathrm{~g}$ AFDM $\mathrm{m}^{-2} \mathrm{yr}^{-1}$ at Sites 1 and 2 respectively. Production of $L$. virgulata was $10.5 \mathrm{~g} \mathrm{AFDM} \mathrm{m}^{-2} \mathrm{yr}^{-1}$ at Site 3. Standing stock biomass of $L$. hebes was 5.2 and $18.3 \mathrm{~g} \mathrm{AFDM} \mathrm{m}^{-2}$ at Sites 1 and 2 respectively. Standing stock biomass of $L$. virgulata was $23.2 \mathrm{~g}$ AFDM $\mathrm{m}^{-2}$ at Site 3 . Thus, the annual production to standing

Table 1 Leptogorgia hebes. Secondary production estimate for Site 1

\begin{tabular}{|ccccc|}
\hline $\begin{array}{c}\text { Age } \\
\text { (yr) }\end{array}$ & $\begin{array}{c}\text { Density } \\
\left(\text { no. m }{ }^{-2}\right)\end{array}$ & $\begin{array}{c}\text { Biomass } \\
\text { (g AFDM m }\end{array}{ }^{-2}$ ) & $\begin{array}{c}\text { Production } \\
\left(\text { (g AFDM m }^{-2} \mathrm{yr}^{-1}\right)\end{array}$ & $\begin{array}{c}P / \bar{B} \\
\left(\mathrm{yr}^{-1}\right)\end{array}$ \\
\hline $0-1$ & 0.16 & 0.14 & 0.10 & 0.71 \\
$1-2$ & 0.27 & 0.44 & 0.24 & 0.54 \\
$2-3$ & 0.55 & 1.47 & 0.69 & 0.47 \\
$3-4$ & 0.52 & 2.17 & 0.90 & 0.41 \\
$4-5$ & 0.12 & 0.75 & 0.29 & 0.39 \\
$5-6$ & 0.02 & 0.18 & 0.07 & 0.39 \\
Total & 1.64 & 5.15 & 2.29 & 0.44 \\
\hline
\end{tabular}

Table 2. Leptogorgia hebes. Secondary production estimate for Site 2

\begin{tabular}{|ccccc|}
\hline $\begin{array}{c}\text { Age } \\
(\mathrm{yr})\end{array}$ & $\begin{array}{c}\text { Density } \\
\left(\text { no. } \mathrm{m}^{-2}\right)\end{array}$ & $\begin{array}{c}\text { Biomass } \\
\left(\mathrm{g} \mathrm{AFDM} \mathrm{m}^{-2}\right)\end{array}$ & $\begin{array}{c}\text { Production } \\
\left(\mathrm{g} \mathrm{AFDM} \mathrm{m}^{-2} \mathrm{yr}^{-1}\right)\end{array}$ & $\begin{array}{c}P / \bar{B} \\
\left(\mathrm{yr}^{-1}\right)\end{array}$ \\
\hline $0-1$ & 0.04 & 0.03 & 0.02 & 0.66 \\
$1-2$ & 0.19 & 0.31 & 0.17 & 0.55 \\
$2-3$ & 0.37 & 0.99 & 0.46 & 0.46 \\
$3-4$ & 0.40 & 1.67 & 0.70 & 0.42 \\
$4-5$ & 0.24 & 1.51 & 0.59 & 0.39 \\
$5-6$ & 0.10 & 0.92 & 0.34 & 0.37 \\
$6--7$ & 0.04 & 0.53 & 0.19 & 0.36 \\
$7-8$ & 0.10 & 1.92 & 0.68 & 0.35 \\
$8-9$ & 0.16 & 4.37 & 1.53 & 0.35 \\
$9-10$ & 0.10 & 3.88 & 1.34 & 0.34 \\
$10-11$ & 0.04 & 2.20 & 0.75 & 0.34 \\
Total & 1.78 & 18.33 & 6.77 & 0.37 \\
\hline
\end{tabular}

Table 3. Leptogorgia virguiata. Secondary production estimate for Site 3

\begin{tabular}{|ccccc|}
\hline $\begin{array}{c}\text { Age } \\
\text { (yr) }\end{array}$ & $\begin{array}{c}\text { Density } \\
\left(\text { no. m } \mathrm{m}^{-2}\right)\end{array}$ & $\begin{array}{c}\text { Biomass } \\
\left(\mathrm{g} \mathrm{AFDM} \mathrm{m}^{-2}\right)\end{array}$ & $\begin{array}{c}\text { Production } \\
\left(\mathrm{g} \mathrm{AFDM} \mathrm{m}^{-2} \mathrm{yr}^{-1}\right)\end{array}$ & $\begin{array}{c}P / \bar{B} \\
\left(\mathrm{Yr}^{-1}\right)\end{array}$ \\
\hline $0-1$ & 0.00 & 0.00 & 0.00 & \\
$1-2$ & 0.34 & 0.16 & 0.33 & 2.06 \\
$2-3$ & 1.10 & 2.60 & 3.07 & 1.18 \\
$3-4$ & 1.18 & 6.07 & 3.29 & 0.54 \\
$4-5$ & 0.70 & 5.56 & 1.95 & 0.35 \\
$5-6$ & 0.42 & 4.50 & 1.17 & 0.26 \\
$6-7$ & 0.14 & 1.89 & 0.39 & 0.20 \\
$7-8$ & 0.00 & 0.00 & 0.00 & \\
$8-9$ & 0.06 & 1.15 & 0.17 & 0.15 \\
$9-10$ & 0.06 & 1.31 & 0.17 & 0.13 \\
Total & 4.00 & 23.24 & 10.54 & 0.45 \\
\hline
\end{tabular}

stock biomass ratios were $0.44,0.37$, and 0.45 at Sites 1,2 , and 3 . The reciprocal of the annual $P / \bar{B}$ ratio is turnover time, or the time it takes to replace the biomass of the population (Benke 1984). This equates to $2.3,2.7$, and 2.2 yr for Sites 1,2 , and 3. The $P / \bar{B}$ ratio declined in general for each successive age class, as might be expected

\section{DISCUSSION}

In the present study, the difference in annual production estimates between Sites 1 (2.3 g AFDM $\left.\mathrm{m}^{-2} \mathrm{yr}^{-1}\right)$ and $2\left(6.8 \mathrm{~g}\right.$ AFDM m$\left.{ }^{-2} \mathrm{yr}^{-1}\right)$ is quite marked and can be attributed to age structure (Tables $1 \& 2$ ) and subsequent standing stock differences (Tables 1 \& 2). Most gorgonian colonies at Site 1 were young and small, while a large percentage at Site 2 were older and larger (Mitchell et al. in press). Leptogorgia virgulata at Site 3 had the highest pro- 
duction (10.5 $\mathrm{g}_{\text {AFDM m}}^{-2} \mathrm{yr}^{-1}$ ) of the 3 sites due to high densities of young colonies (Table 3 ). The longer turnover time at Site $2(2.70$ vs 2.27 and 2.22 at Sites 1 and 3 ) indicates older, larger colonies (higher biomass). The general decline in $P / \bar{B}$ ratios with each successive age class (Tables 1 to 3 ) is a function of larger, older individuals contributing much to population biomass but a lower fraction to production (Robertson 1979).

Most coral production studies are energy flow estimates based on oxygen measurements fOdum \& Odum 1955, Kanwisher \& Wainwright 1967, Davies 1980, Lewis \& Post 1982). If our AFDM estimates are converted to energy values ( $\mathrm{g} A F D M \times 5 \approx \mathrm{kcal}_{\text {; }}$ Crisp 1975), we obtain 12,34, and $53 \mathrm{kcal} \mathrm{m}^{-2} \mathrm{yr}^{-1}$ at Sites 1 , 2 , and 3 respectively. These figures are similar to the scleractinian coral production estimates reported by Lewis (1981), which ranged from 29 to $57 \mathrm{kcal} \mathrm{m}^{-2} \mathrm{yr}^{-1}$ for 5 of the 6 species; the sixth was estimated at

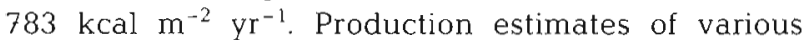
marine benthic populations presented by both Warwick (1980) and Lewis (1981) exhibited a wide range of values, although most were below $50 \mathrm{kcal} \mathrm{m}^{-2} \mathrm{yr}^{-1}$.

Ash-free dry mass comprises a relatively low percentage of total coenenchyme dry mass due to the presence of calcareous spicules embedded in the tissue. AFDM percentages were 8.9 for Leptogorgia hebes and 9.3 for $L$. virgulata. These fall within the range ( 9 to 24 ) of 5 species of tropical gorgonians reported by Lewis \& Post (1982), but were lower than values (16 to 71) presented by Vreeland \& Lasker (1989)

The relative importance of autotrophic versus heterotrophic nutrition in gorgonians is unclear (Muscatine 1973), since endosymbiotic zooxanthellae may contribute some fraction of biomass accumulation by primary production. Although Leptogorgia setacea has been reported to have zooxanthellae (Ciereszko 1962), some species remain asymbiotic, particularly those found at greater depths (Goldberg 1973, Kinzie 1973). Since our populations are found at low light levels $\left[11.5( \pm 0.6 \mathrm{SE}) \mu \mathrm{E} \mathrm{s}^{-1} \mathrm{~m}^{-2}\right.$ at Site 2 in winter] at all 3 northern Gulf study sites due to depth, turbidity or both, autotrophic nutrition probably plays a relatively minor role in production under these conditions.

Production estimates reported in this study are likely to be conservative because they include only biomass gained from year to year and do not measure production lost to nonlethal predation or as mucus. Gorgonians have parasites and predators, including the snails Cyphoma gibbosum and Simnialena uniplicata, a polychaete Hermodice carunculata and the Atlantic spadefish Chaetodipterus faber. However, despite reports that more tissue may be lost to grazing in Caribbean communities than is replaced (Vreeland \& Lasker 1989) and the array of potential predators in the northern Gulf, little evidence of grazing, in the form of damaged tips, feeding scars or regenerated tissue, was observed on the colonies we examined. Mucus has long been viewed as a source of energy transfer in coral reef systems (Johannes 1967, Qasim \& Sankaranarayanan 1970, Benson \& Muscatine 1974, Coffroth 1990). Mucus sheet production by the gorgonian Briarium asbestinum (Octocorallia: Gorgoniidae) from the Miami, Florida region was approximately $1.6 \mathrm{~g}$ dry mass $\mathrm{m}^{-2} \mathrm{yr}^{-1}$ (calculated from Rublee et al. 1980). Leptogorgia hebes in the northern gulf also produced mucus but we were unable to document regular or predictable intervals. Coffroth (1988) suggested that because of the low energy value and episodic nature of mucus sheets, they do not play a substantial role in reef food webs.

Our analyses represent an approach to estimating production of gorgonian corals based upon annual biomass accumulation. This first attempt to measure productivity by a dominant species on deep temperate reefs suffers from small samples sizes and large variances, common deficiencies when dealing with populations that are difficult to sample. Our values, however, represent an initial estimate of the contribution of an important faunal component of an offshore habitat that provides cover and feeding areas for many fishes and invertebrates (Cummins et al. 1962, Buchanan 1973, Bright et al. 1981). While not explicitly accounting for non-lethal predation and mucus production, it provides a base value for production that probably represents a high fraction of the total.

Acknowledgements. This project was supported in part by NOAA Office of Sea Grant, Department of Commerce, under Grant Nos. NA85AA-D-SG005, and NA89AA-DSG016 (Projects R/ER-19-PD, R/ER-19, and E/O-16), the Mississuppi-Alabama Sea Grant Consortium, NOAA's National Undersea Research Center at the University of North Carolina at Wilmington under Grant No. NA88AA-DUR004, The University of Alabama and the Marine Environmental Sciences Consortium. Fellowship support for N.D.M. was received from the Mississippi-Alabama Sea Grant Consortium, the Patricia Roberts-Harris Foundation through The University of Alabama, and the Mobil and Shell Oil Company Foundations through the Marine Environmental Sciences Consortium. F. M. Bayer courteously verified the gorgonian species in this study. Thanks also go to everyone who aided in field collections especially to $\mathrm{J}$ Dindo for making numerous offshore dives possible, and to C. Wood for her typing assistance. Review by J. Valentine substantially improved the manuscript. This represents Contribution Number 192 of the Marine Environmental Sciences Consortium and Contribution Number 190 from the University of Alabama Aquatic Biology Program. 


\section{LITERATURE CITED}

Abston, J. R., Dinnel, S. P., Schroeder, W. W., Schultz, A. W. Wiseman, W. M. Jr (1987). Coastal sediment plume morphology and its relationship to environmental forcing: Main Pass, Mobile Bay. Alabama. In: Kraus, N. C. (ed.) Coastal Sediments 87 Waterway Division/American Society of Civil Engineers, New Orleans, p 1989-2005

Barnes, R. D. (1980). Invertebrate zoology. Saunders College Publ., Philadelphia

Bayer, F. M. (1961). The shallow-water Octocorallia of the West Indian Region: a manual for marine biologists. Martinus Nijhoff, The Hague, Netherlands

Benayahu, Y. (1985). Faunistic composition and patterns in the distribution of soft corals (Octocorallia: Alyconacea) along the coral reefs of Sinai Peninsula. In: Gabrie, C., et al. (eds.) Proc. 5th int. coral Reef Congr., Tahiti 6: 255-260

Benke, A. C. (1984). Secondary production of aquatic insects In: Resh, V H., Rosenberg, D. M. (eds.) The ecology of aquatic insects. Praeger, New York, p. 289-322

Benson, A. A. Niuscatine, L. (1974). Wax in coral mucus energy transfer from corals to reef fishes. Limnol Oceanogr. 19: 810-814

Bright, T., Jaap, W., Cashman, C. (1981). Ecology and management of coral reefs and organic banks. In: Atwood, D. $K$. (ed.) Environmental research needs in the Gulf of Mexico, Vol IIB. NOAA/ERL Atlantic Oceanogr. Meteorol Lab, Miami, p. 53-160

Buchanan, C. C. (1973). Effects of an artificial habitat on the marine sport fishery and economy of Murrells Inlet, South Carolina. Mar. Fish. Rev. 351 15-22

Ciereszko, L. S. (1962). Chemistry of coelenterates. III Occurrence of antimicrobial terpenoid compounds in zooxanthellae of alcyonarians. Trans. N.Y Acad. Sci. 92: 502-503

Coffroth, M. A. (1988). The function and fate of mucus sheets produced by reef coelenterates. In: Choat, J. H. et al. (eds.) Proc. 6th int. coral Reef Symp. 2: 15-20

Coffroth, M. A. (1990). Mucous sheet formation on poritid corals: an evaluation of coral mucus as a nutrient source on reefs. Mar. Biol. 105: 39-49

Crisp, D. J. (1975). Secondary productivity in the sea. In: Productivity of world ecosystems. Proc. int. Biol. Prog. Symp., Natl. Acad. Sci., p. 71-89

Crisp, D. J. (1984). Energy flow measurements. In: Holme, N. A., McIntyre, A. D. (eds.) Methods for the study of marine benthos. I. B. P. Handbook No. 16, Blackwell Scientific, Oxford, p. 284-372

Cummins, R. Jr, Rivers, J. B., Struhsaker, P. (1962). Snapper trawling explorations along the southeastern coast of the United States. Comml. Fish. Rev. 14(12): 1-7

Curray, J. R. (1960). Sediments and history of Holocene transgression, continental shelf, northwest Gulf of Mexico. In: Shepard, F. P., Phleger, F. B., Van Andel, T H. (eds.) Recent sediments, northwest Gulf of Mexico. Am. Ass. Petrol. Geol., Tulsa, p. 221-266

Davies, P. S. (1980). Respiration in some Atlantıc reef corals in relation to vertical distribution and growth form. Biol. Bull. 158: $187-194$

Dinnel, S. P., Schroeder, W. W., Wiseman, W. J. Jr (1990). Estuarine-shelf exchange using Landsat images of discharge plumes. J. coast. Res, 6(4):789-799

Goldberg, W. M. (1973). The ecology of the coral-octocora] communities off the southwest Florida coast: geomorphology, species composition and zonation. Bull. mar. Sci. 23: $465-488$
Gotelli, N. J. (1988). Determinants of recruitment, juvenile growth, and spatial distribution of a shallow-water gorgonian. Ecology 69: 157-166

Grasshoff, M. (1988). The genus Leptogorgia (Octocorallıa Gorgoniidae) in West Africa. Atlantide-Report 14: 91-147

Grigg, R. W. (1977). Population dynamics of two gorgonian corals. Ecology 58: 278-290

Harrod, J. J., Hall, R. E. (1962). A method for determining the surface areas of various aquatic plants. Hydrobiologia 20: $173-178$

Hicks, G. R. (1977). Species composition and zoogeography of marine phytal harpacticoid copepods from Cook Strait, and their contribution to total phytal meiofauna. N.Z. J. mar. Freshwat. Res. 11: 441-69

Johannes, R. E. (1967). Ecology of organic aggregates in the vicinity of a coral reef. Limnol. Oceanogr 12: 189-195

Kanwisher, J. W., Wainwright, S. A. (1967). Oxygen balance in some reef corals. Biol. Bull. 1.33: 378-390

Kinzie, R. A. (1973). The zonation of West Indian gorgonians Bull. mar. Sci. 23: 93-155

Lewis, J. B. (1981). Estimates of secondary production of reef corals. In: Taylor, D. L. (ed.) Proc. 4th int coral Reef Symp. 2: $369-373$

Lewis, J. B., Post, E. E. (1982). Respiration and energetics in West Indian Gorgonacea (Anthozoa, Octocorallia). Comp. Biochem. Physiol. 71: 457-459

Ludwick, J. C. (1964). Sediments in Northeastern Gulf of Mexico. In: Miller, R. L. (ed.) Papers in marine geology. MacMillan and Co. Publ., New York, p. 204-238

Mitchell, N. D., Dardeau, M. R., Schroeder, W. W. (in press) Colony morphology, age structure and growth of two gorgonian corals, Leptogorgia hebes (Verrill) and Leptogorgia virgulata (Lamarck) from the northern Gulf of Mexico. Coral Reefs

Muscatine, L. (1973). Nutrition of corals. In: Jones, O. A., Endean, R. (eds.) Biology and geology of coral reefs. Vol. 2 Biology 1. Academic Press, New York, p. 77-11.6

Odum, H. T., Odum, E. P. (1955). Trophic structure and productivity of a windward coral reef community on Eniwetok Atoll. Ecol. Monogr. 25: 291-320

Parker, R. O., Colby, D. R., Willis, T D. (1983). Estimated amount of reef habitat on a portion of the U.S. South Atlantic and Gulf of Mexico Continental Shelf. Bull. mar. Sci. 33(4): $935-940$

Qasim, S. Z., Sankaranarayanan, V. N. (1970). Production of particulate organic matter by the reef on Kavaratti Atoll (Laccadives). Limnol. Oceanogr. 15: 574-578

Robertson, A. 1. (1979). The relationship between annual production: biomass ratios and lifespans for marıne macrobenthos. Oecologia 38: 193-202

Rublee, P. A., Lasker, H. R., Gottfried, M., Roman, M. R. (1980). Production and bacterial colonization of mucus from the soft coral Briarium asbestinum. Bull. mar. Sci. 30 $888-893$

Schroeder, W. W., Dardeau, M. R., Dindo, J. J., Fleischer, P., Heck, K. L. Jr, Shultz, A. W. (1988a). Geological and biological aspects of hardbottom environments on the L'MAFLA shelf, northern Gulf of Mexico. In: Proc. Oceans '88 Conf. Marine Technology Society and Oceanic Engineering Society, Institute of Electrical and Electronics Engineers, New York, p. 17-21

Schroeder, W. W., Shultz, A. W., Dindo, J. J. (1988b). Innershelf hardbottom area, northeastern Gulf of Mexico. Trans. Gulf Coast Assoc. Geol. Soc. 38: 535-541

Schroeder, W. W., Gittings, S. R., Dardeau, M. R., Fleischer, P., Sager, W. W., Shultz, A. W., Rezak, R. (1989). Topographic features of the L'MAFLA continental shelf, northern 
Gulf of Mexico. In: Proc. Oceans '89 Conf. Marine Technology Society and Oceanic Engineering Society, Institute of Electrical and Electronics Engineers, New York, p. $54-57$

Vreeland, H. V., Lasker, H. R. (1989). Selective feeding of the polychaete Hermodice carunculata Pallas on Caribbean gorgonians. J. exp. mar. Biol. Ecol. 129: 265-277

Warwick, R. M. (1980). Population dynamics and secondary production of benthos. In: Tenore, K. R., Coull, B. C. (eds.)

This article was submitted to the editor
Marine benthic dynamics. Univ. South Carolina Press, Columbia, p. 1-24

Waters, T F. (1977). Secondary production in inland waters. Adv. ecol. Res. 10: 91-164

Wendt, P. H., van Dolah, R. F., O'Rourke, C. B. (1985). A comparative study of the invertebrate macrofauna associated with seven sponge and coral species collected from the South Atlantic Bight. J. Elisha Mitchell Sci. Soc. 101: $187-203$

Manuscript first received: May 12, 1992

Revised version accepted: August 28, 1992 